\title{
$11>0$
}

\section{新たな計量標準の整備計画* \\ The New Development Plan of Measurement Standards}

\section{藤井克宜* \\ Katsunori FUJII}

Key words intellectual infrastructure, measurement standard

\section{1.は じめに}

わが国の国際競争力の維持・強化, イノベーション促 進，企業活動の信頼性向上，中堅・中小企業のものづくり 基盤，国民生活の安全・安心の確保等を図るため, 計量標 準，微生物遺伝資源，地質情報等の「知的基盤」は，国の 公共財・ソフトインフラとして, 道路, 下水道等に代表さ れるハードインフラの整備と同様に国の責務として整備さ れ，国民生活や社会経済活動を幅広く支えている。

わが国の知的基盤の整備施策は科学技術基本計画に基づ き進められている。

現在の整備施策は, 2013 年 8 月に閣議決定した第 4 期 科学技術基本計画に基づき，昨年度，知的基盤整備特別小 委員会により策定された「新たな知的基盤整備計画及び具 体な利用促進方策」に沿って実施されている。

本稿では，この「新たな知的基盤整備計画及び具体な利 用促進方策」の中から, 精密工学分野と関係の深い「計量 標準に関する新たな整備計画・利用促進方策」のうちの物 理標準に関わる章を中心に述べることとする。

\section{2. 計 量 標 準}

国民生活，企業に扮ける事業活動や研究活動において, ものを測ることは必要不可欠なことである.

また，測定の正確性を確保するには，測定器の正確性と 測定方法の適切性の双方を確保していくことが重要であ り，測定器の正確性を確保するためには，目的に合った信 頼性ある測定器を選択するとともに，測定器のメンテナン スとして，定期的な保守点検，校正が重要である。

校正とは計測器の指示值や実量器 (分銅等) のもつ值と その不確かさとを, 計量標準に基づいて決めることをい い，計測器は，適切に校正することで，初めて信頼しうる 測定值を表示することができる.

ここで計量標準は，国際計量計測用語 JIS TS Z0032

*原稿受付 平成 26 年 4 月 22 日

*経済産業省産業技術環境局知的基盤課（東京都千代田区霞が関 1 丁目 3 番 1 号)
(VIM) において「何らかの計量参照として用いるため の，表記された量の值及び付随する測定不確かさをもつ， 值の定義の具体化」と定義されている「測定標準（measurement standard)」のことである.

計量標準は，ものを測る基準として，国民の一人ひとり の日常生活, 事業者の活動, 大学, 研究機関等の研究開発 などあらゆる場面で, 測定器および測定サービスなどを通 して，幅広く利用されている。

\section{3. 従前の計量標準整備状況}

新たな整備計画について説明する前に, これまでの計量 標準整備政策について触れておきたい.

2001 年 3 月に閣議決定された第 2 期科学技術基本計画 では 2010 年を目途に世界最高の水準を目指し整備を行う こととされ，これを受け，経済産業省は2010年度までに 計量標準について欧米並みの 250 種類程度の整備を行う数 值目標を示した「計量標準整備計画」を公表した。

この計画策定当時，わが国の計量標準は 100 種類程度の 整備状況であり，意外に思われるかもしれないが，わずか 十数年前までわが国は欧米と比べ計量標準の整備が大きく 遅れている状況にあった。

この計画に沿って日本の国家計量標準の整備・維持を担 っている独立行政法人産業技術総合研究所が中心となり, 関係機関と連携, 協力しながら鋭意計量標準の整備を進め た結果, 2010 年度末には 303 種の計量標準が整備され, 当初の目標を大幅に上回る結果となった。

\section{4. 新たな計量標準の整備計画策定の経緯}

先述した「計量標準整備計画」を達成したのちの 2011 年 8 月に閣議決定された第 4 期科学技術基本計画では, 多 様な利用者ニーズに応えるため, 質の充実の観点も踏まえ つつ, 知的基盤の整備を促進することとし, 国は新たな整 備計画を作成することとされた。

これを受け，経済産業省では，ユーザー，有識者等に対 して，ヒアリング，意見交換等を行い，ユーザーニーズ， 問題点の整理を行った。 
これを踏まえ 2012 年 4 月から, 計 4 回にわたり産業構 造審議会・日本工業標準調查会の合同会議である知的基盤 整備特別委員会が開催され，今後の新たな知的基盤の整 備・利用促進の方針および具体的方策の検討を行い，同年 8月に中間報告が取りまとめられ，この報告で打ち出され た方針や方策に沿って検討が重ねられた結果, 2013 年度 に「新たな知的基盤整備計画及び具体な利用促進方策」が 知的基盤整備特別小委員会により策定されたのである.

\section{5. 新たな計量標準の整備計画}

新たな計量標準（物理標準）の整備計画は, 以下の 5 つ の基本的考え方に基づいて策定されている.

\section{（1）新たな計測ニーズに応える計量標準整備}

今日, 気候変動, 地球環境, エネルギー, 医療, 食品等 の分野は国際的にも国内的にも重要な課題となってきてお り, 第 4 期科学技術基本計画に扔いても震災対応と並ん で,グリーンイノベーションの推進拉よびライフイノベー ションの推進が提言されているところである。 このような 課題に対して計量標準を整備することにより, 必要な計測 や分析の結果に正確性と信頼性を付与し, 研究開発の推 進, 市場の創生, 新製品の生産性と品質の向上等を支援す ることは，わが国の将来にとって不可欠である。また，情 報通信, ナノテクノロジー, 材料, ロボット等はわが国の ものづくりの中核的な分野であり, 経済産業省がまとめた 技術戦略マップ 2010 に扔いても，技術開発のロードマッ プが詳細に示されている。これらものづくりに関わる円滑 な研究開発や製品化を支援するため, 必要な計量標準を拡 充する必要がある.

(2) SI 基本単位の高度化に関わる研究開発

SI は現在の計量・計測を支える単位系であり, SI を構 築する 7 つの基本単位は, 基礎科学や産業技術と深く関わ っており，先進国の国家計量標準機関（わが国においては 産業技術総合研究所）は基本単位の研究を重ねてきた。 2011 年の第 24 回国際度量衡総会で, 基礎物理定数に基づ く基本単位の再定義の指針が示され，近い将来想定される キログラム, アンペア, ケルビン, モルの改定の方向性が 示された，新しい基本単位の定義に向けて国家計量標準機 関には, 基本単位を定義するために必要な物理定数の精密 な測定，ならびに基本単位の定義を実現する方法の研究が 求められている.

（3）これまで整備した計量標準の質の向上

第 1 期計量標準整備計画（2001 年度～2010 年度）にお いては, 欧米に比肩する量目を整備することを目指し, 計 量標準 (物理標準) と標準物質をそれぞれ 250 種整備する という数値目標を設定した。これらの目標は達成され, 日 本として必要な基本的な量目の整備が完了したところであ る.

これまで整備した計量標準に対する多様なユーザーニー ズを踏まえ, 標準の供給範囲の拡張, 校正技術の高度化, 不確かさの低減など標準の質の向上を図る取り組みも必要
である。

（4）新たな整備計画に扔ける重点分野

新たな整備計画の策定にあたっては, 以下の 7 つの項目 を重点分野とし、 ユーザーの視点に留意し，そのニーズに 応えるとともに, 国の優先課題を踏まえた選択と集中を図 ることが重要である.

(1) 震災対応

(2) グリーンイノベーション・インフラの整備

(3) ライフイノベーション・インフラの整備

(4) 日本が強みを有するものづくり基盤支援

(5) 産業の国際展開

(6) 規制への対応

(7) SI 基本単位に係る整備

（5）具体的な整備方策の策定

新たな整備計画に基づく標準供給とともに, 計睑器や校 正サービスを受ける利用者の利便性を図るための整備方策 の検討が必要である.

2012 年 8 月の中間報告, ユーザーニーズ調査やヒアリ ングを踏まえ, 複数量目の計測機器の校正の取り扱い, 求 められる技術水準に即した登録審査など制度運用の改善, 2 次標準器の開発, 官民の役割分担の見直しを図るなど円 滑な標準供給の促進を図ることが重要である.

今後 10 年先までという長期的な視野で, これらの方針 に基づいて計量標準整備に取り組むにあたっては, 計画に 基づき着実に整備を実施していくだけではなく, 科学技術 の進歩, 産業や経済情勢などにより変化していく計量, 校 正に対するユーザーニーズの動向，また，技術開発に伴い 広がっていく整備可能な計量標準の種類や供給範囲の拡大 等に応じた弾力的かつ迅速な対応も求められる。

本整備計画では, その時々の状況に応じたユーザーニー ズ等を的確に波み取り, 計画自体の変更も行える柔軟なも のとするため, PDCA サイクルを回し, 定期的な計画の 見直しを行っていくこととしているのである.

以上を踏まえ, 今般策定された本整備計画について紹介 する。

表 1 に示すのは整備項目の件数を分野別に集計したも のである。な挔, 表中の 2013 年度 7 月時点の欄に記載す る整備件数は, 2010 年度末時点での計量標準整備数 303 種に，その後の整備状況を加えたものである（2010 年度 以降の整備については, 既存標準に㧈ける範囲拡張整備も 含んだ整備件数).

2001 2010 年度の計量標準整備計画において, 各量目 とも基本的な整備が抄抄よそ完了していることから, 内容 としては範囲の拡張が整備の主体となっている.

一方で, 電気 (高周波) 関連量や光放射関連量などの分 野では, 新たな校正原理・整備等に基づく新規計量標準開 発も行われる。

分野別の標準整備計画概要は以下のとおりである.

(a) 時間周波数

新しい秒の定義候補として採用され，より高精度な時間 
表 1 計量標準整備計画 分野別整備項目数 (件)

\begin{tabular}{l|r|r|r|r}
\hline \multirow{2}{*}{ 量目区分 } & 2013 年 & \multicolumn{3}{c}{$2013 \sim 2022$ 年度 } \\
\cline { 3 - 5 } & 7 月時点 & 新規 & 拡張 & 合計 \\
\hline SI 基本単位 & - & 3 & 1 & 4 \\
\hline 時間周波数 & 7 & 0 & 2 & 2 \\
\hline 長さ & 35 & 4 & 3 & 7 \\
\hline 質量 & 4 & 0 & 1 & 1 \\
\hline トルク & 5 & 0 & 2 & 2 \\
\hline 圧力 & 19 & 0 & 4 & 4 \\
\hline 振動加速度 (加速度) & 7 & 2 & 1 & 3 \\
\hline 音響・超音波 & 10 & 4 & 1 & 5 \\
\hline 硬さ & 5 & 0 & 2 & 2 \\
\hline 温度・湿度 & 44 & 1 & 6 & 7 \\
\hline 流量 & 17 & 1 & 4 & 5 \\
\hline 固体物性 & 13 & 1 & 4 & 5 \\
\hline 密度・屈折率 & 9 & 3 & 2 & 5 \\
\hline 直流・低周波電気量 & 57 & 2 & 2 & 4 \\
\hline 高周波電気量 & 41 & 10 & 7 & 17 \\
\hline 光 & 34 & 7 & 9 & 16 \\
\hline 放射線・放射能・中性子 & 25 & 3 & 10 & 13 \\
\hline 粒子・粉体特性 & 5 & 1 & 3 & 4 \\
\hline そのほか & 8 & - & - & - \\
\hline 合計 & 344 & 42 & 64 & 106 \\
\hline
\end{tabular}

標準として期待される光格子時計の研究開発に注力し, 協 定世界時の決定などに寄与する。また周波数遠隔校正の利 便性向上，持込校正能力の向上を図る.

(b) 長さ・幾何学量

社会情勢や技術の変化によって新たに必要となったナノ スケール標準のほか, 新たな幾何学量標準として X 線 CT による内部形状標準，二次元グリッド標準を整備する.

(c) 力学量

基礎物理定数に基づくキログラム定義改定の利点を生か した微小質量標準の開発を進める。製品の小型化に対応し た小容量トルク標準, 燃料電池車用水素供給インフラを支 える気体高圧力標準, 先端科学技術に貢献する超高真空 標準, フロン規制等で必要なリーク標準の整備・拡充を 行う.

（d）音響・超音波

環境ラベル取得用途等で強いニーズのある音響パワーレ ベル標準を中心に整備する。国際規格に適合した医用超音 波機器の性能・安全性評価に必要な超音波パワー等の超音 波関連標準を整備する。

(e) 振動 · 硬さ

自動車産業や精密機器産業における安全性確保に関わる 衝撃加速度, 角振動等の加速度標準, および産業ニーズが 大きいロックウェル B スケール硬さ等の硬さ関連標準の 整備に注力する.

(f) 温度 · 湿度

金属-炭素共晶点を用いた $2000^{\circ} \mathrm{C}$ 付近の熱電対校正用高 温標準, 多種ガス中微量水分標準, 熱画像装置校正用放射 温度標準，低温度標準においても $50 \mathrm{mK} \sim 0.65 \mathrm{~K}$ の供給 範囲の拡大など，最先端産業分野のニーズに適確にこたえ る標準整備, 温度範囲の拡張などを進める。 (g) 流量・流速

これまでに整備した世界屈指の石油流量, 気体流量等の 国家標準のガス種・液種拡大，範囲拡張を進めるととも に, これらを活用しつつ, 高性能な参照用流量計といった 仲介器の開発や計測法の検証, 国内外の工業規格の制定 · 改定などを通して, トレーサビリティ体系の確立, 利用促 進を図る。

(h) 固体物性

熱流密度, 熱拡散率, 熱膨張率など, 広範なニーズに応 じて標準供給範囲を継続的に拡充する。依頼試験により産 業分野それぞれの用途, 条件に応じた個別案件に対応しつ つ, より有用性の高い標準物質による供給体系の構築を推 進する。

(i) 密度, 屈折率, 粘度

PVT 性質（流体の温度, 圧力, 密度の性質）や海水密 度などについて，これまで確立してきた高精度なトレーサ ビリティ体系とその校正技術に基づき SI トレーサブル （国際単位系（SI）に基づく標準までトレーサビリティが 確保されていること）な信頼性の高い標準物質, 標準デー 夕供給へ展開する。

（j）直流 · 低周波電気量

法規制およびスマートメータなどのエネルギー対策にお いてニーズの高い高調波電圧・電流, 交流シャント等の標 準整備を重視するとともに，既存標準の利用促進を目的と した小型 2 次標準電圧発生器・標準抵抗器の開発を行う。

(k) 高周波電気量

スーパーハイビジョン中継など大容量デー夕無線通信の ため, 無線周波数の高周波化開発が進められ, また, 低周 波の $\mathrm{EMC}$ 規制への対応などから, 高周波電力, インピー ダンス, 減衰量, アンテナ利得等の各量目に関して, 周波 数範囲を拡張し $9 \mathrm{kHz}$ 300 GHz 超までの標準整備を進め る。また超高周波帯標準量として, レーダー散乱断面積や 誘電率の標準を新規開発する。

(1) 光放射

LED 照明などの全光束測定等においてニーズが高い分 光全放射束標準, 光ファイバ線路のリアルタイム計測に用 いられるOTDR 装置（光パルス試験器）用標準など, 現 場計測や製品評価でのニーズが高いにもかかわらず，既存 の光放射関連標準だけでは事業者側での組み立てが困難な 標準量の整備を進める。

（m）放射線・放射能・中性子

放射線・放射能については, 要請の高い診断・治療に必 要な標準整備に注力し, 中性子については, 引き続き, 基 本・基盤的な品目の整備を進める。また，産業に必要な高 線量水吸収線量等の標準の開発を進める。さらに，震災後 の復興に際して，新たなニーズが生じた低線量率放射線， 環境レベル放射能, 線量当量について開発を行う.

(n) 粒子

法規制や産業ニーズの高い分野の要請に対応し, 粒径標 準のナノメートル域への微小化（ナノ安全対応）, 気中粒 
子数濃度標準の濃度範囲拡大（ディーゼルナノ粒子等規制 対応), および液中粒子数濃度標準の小粒径化（医療・診 断のトレーサビリティ等対応）を進める。

\section{6. 計量標準の利用促進に向かって}

計量標準はただ整備しているのみではその価値はなく, ユーザーに利用されてこそインフラとして価值を発揮する ものである

国家計量標準を校正サービスを通してエンドユーザーに 利用されるための供給形態の一つである JCSS（Japan Calibration Service System）の利用件数（登録事業者の数 や校正証明書の発行件数）も関係者の努力により年々増加 はしているところではあるものの，中堅・中小企業の多く は, 計量標準の整備・供給状況，校正サービス等を知らな い現状にある。

今回，整備計画と同時に策定された利用促進方策では， 計量標準の幅広い普及のため, 日本の製造業を支える中 堅・中小企業を利用促進方策の対象ユーザーの中心とし， 国家計量標準や計量標準供給制度を知ってもらうべく，以 下の基本的な考え方の下，利用促進方策を打ち出したとこ ろである。

(1) 中堅·中小企業の活動支援

中堅・中小企業に計量標準供給制度を利用してもらうた めには，商取引・証明，規制対応や基準適合などにおける 必要性を理解してもらった上で, 利用者の負担軽減など使 いやすい環境整備を図ることが必要である。

(2) 情報提供のあり方の見直し
製造事業者が計量標準や校正に関する情報にアクセスす る機会が非常に少なく, また, 専門用語が多く, わかりに くい情報が提供されていることを踏まえ, わかりやすく使 いやすい情報提供ツールを検討する.

(3) 計量標準の利用促進に向けた環境整備

上記の利用促進を可能とするため, 関係機関が連携, 協 力し, 情報基盤整備, 地域拠点整備, 活動基盤整備など環 境整備に取り組むことが重要である.

\section{7.おわりに}

今後の計量標準の整備計画においては精密工学会会員の 皆様をはじめとする計量標準ユーザー, 専門家の皆様の二 ーズやご意見がPDCA を行う際の重要な判断材料となる.

また，将来技術が進歩するにつれ，高度な研究に必要と なるより精密な計測, その計測を支える校正のための世界 最高水準の計量標準の整備に向けて, 官民連携等, 関係者 一丸となったオールジャパンの取り組みが必要となってく ることから，今後とも経済産業行政へのご理解とご協力を 賜りたい.

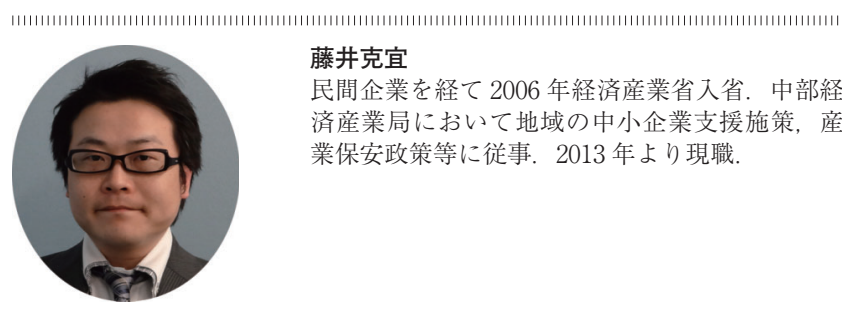

| 